PROFESI (Profesional Islam)

Media Publikasi Penelitian; 2017; Volume 15; No 1.

Website: ejournal.stikespku.ac.id

\title{
Tingkat Depresi Dan Kualitas Hidup Pasien Gagal Ginjal Kronik (GGK) Berdasarkan Tingkatan Usia di RSUD Dr. H. Soewondho Kendal
}

\author{
Siti Aminah ${ }^{1 *}$, \\ ${ }^{1}$ Program Studi D3 Keperawatan, Akper Muhammadiyah Kendal \\ *Email: sitiaminah.maulana@gmail.com
}

Kata Kunci

Depresi;

Usia;

Kualitas hidup;

GGK

\begin{abstract}
Abstrak
Berbagai masalah yang menyertai GGK menyebabkan penderitanya frustasi dan depresi. Depresi berpengaruh terhadap kualitas hidup dan harapan hidup pasien GGK. Salah satu faktor yang mempengaruhi tingkat depresi dan kualitas hidup adalah usia. Tujuan penelitian ini untuk mengetahui hubungan tingkat depresi dengan kualitas hidup pada pasien gagal ginjal kronis (GGK) di RSUD dr. H. Soewondho Kendal. Jenis penelitian ini adalah kuantitatif dengan pendekatan korelasi deskriptif digunakan pada 42 responden pasien GGK yang menjalani hemodialisa di RSUD dr. H. Soewondho Kendal. Hasil penelitian ini adalah sebagian besar responden usia dewasa tidak mengalami depresi (57,89\%), sedangkan sebagian besar responden usia dewasa muda (52,17\%) mengalami depresi. Responden dewasa muda memiliki kualitas hidup dibawah rata-rata lebih banyak $(21,05 \%)$ bila dibandingkan dengan responden dewasa (13,63\%). Ada hubunganyang negatif antara tingkat depresi dengan kualitas hidup pasien GGK dengan r-value $=-0,450$ dan p-value 0,000 ( $p$ value $<0,05)$. Ada hubungan yang negatif antara tingkat depresi dengan kualitas hidup pada pasien gagal ginjal kronik (GGK) di RSUD dr. $H$. Soewondho Kendal. Artinya, semakin depresi seseorang, semakin buruk kualitas hidupnya.
\end{abstract}

\section{The Correlation Between Depression And Quality Of Life Among ESRD Patients Based on Age Level In Dr. H. Soewondho Hospital Kendal State}

\begin{abstract}
End Stage Renal Disease (ESRD) patients encounter many problems that make them frustrated and depressed. Depression is linked with poor quality of life and higher mortality. Age is one of the factors that affect depression and quality of life. The research aims of this study was to investigate the correlation between depression and quality of life among ESRD patients in $d r$. $H$. Soewondho Hospital Kendal State. The research used quantitative design with descriptive-correlational approach was used to investigate the correlation between depression level and quality of life among 42 respondents with ESRD. The result of research were most of adulthood was not depressed (57,89\%), and most of young adulthood respondents were depressed (52,17\%). More young adulthood respondents $(21,05 \%)$ have poorer quality of life than the adulthood respondents (13,63\%). There was a negative correlation between depression level and quality of life among ESRD patient with $r$-value $=-0,450$ and $p$-value 0,000 ( $p$-value $<0,05$ ). There was a negative correlation between depression level and quality of life among ESRD patients, it means, the more depression a person is, the poorer his quality of life is, and the less depression a person is, the better his quality of life.
\end{abstract}




\section{PENDAHULUAN}

Menurut Fresenius Medical Care (2011), jumlah pasien Gagal Ginjal Kronis (GGK) diseluruh dunia pada akhir tahun 2011 mencapai 2.786.000 orang, dengan rata-rata bertambah 6$7 \%$ pertahunnya, dan terus meningkat secara signifikan diseluruh dunia. Taiwan merupakan negara dengan jumlah penderita GGK tertinggi di dunia, dengan jumlah penderita mencapai 2.850 orang per satu juta populasi, diikuti oleh Jepang diurutan kedua, dan Amerika Serikat di urutan ketiga (Fresenius Medical Care, 2011., \& USRDS Annual Data report, 2012).

Di wilayah Asia, berdasarkan data dari Kementrian Kesehatan Republik Indonesia tahun 2014, Indonesia masuk kedalam sepuluh besar negara dengan jumlah kasus GGK tertinggi, dengan jumlah kasus mencapai 504.248, dengan demikian dapat diartikan bahwa dari satu juta penduduk Indonesia ada 400 orang yang menderita gagal ginjal kronik (Berita satu.com, 2014). Sejalan dengan terus bertambahnya jumlah penderita GGK, kematian akibat GGK juga tinggi. GGK bertanggung jawab atas 1,5\% kematian didunia pada tahun 2012 (WHO, 2014). Setiap harinya 50 orang meninggal karena gagal ginjal (Kidney Health Australia, 2009).

Kehilangan fungsi ginjal menyebabkan penderitanya harus melakukan terapi hemodialisa (HD) seumur hidupnya. Terapi ini dapat memperpanjang hidup pasien dengan menggantikan fungsi ginjal, tanpa terapi ini penderita GGK akan meninggal (Ritmann, Northsea, Hausauer, Green, \& Swanson, 1993 cit Charuwanno, 2005). Hidup dengan GGK membuat penderitanya menghadapi banyak permasalahan, termasuk masalah fisik, psikologis, sosial, ekonomi, dan masalah keluarga yang berdampak pada kualitas hidup penderitanya (Charuwano, 2005).

Depresi merupakan masalah psikologis yang paling sering dialami oleh penderita GGK (Armaly, 2012). Cukor (2007), dalam penelitiannya menyebutkan bahwa $20-30 \%$ penderita GGK mengalami depresi (Cukor, 2007 cit Finkelstein, Wuerth, \& Troidle, 2008). Masalah depresi ini muncul akibat mereka bersalah pada keluarga karena menyebabkan masalah finansial, selain itu takut akan masa depan, merasa tidak berguna, dan terjebak dalam rutinitas terapi membuat mereka merasa frustasi dan depresi.
Menurut Lopez, Albert, dan Young (2004), depresi dikaitkan dengan resiko hospitalisasi, kematian, dan kualitas hidup yang buruk. Walau bagaimanapun, tidak semua penderita GGK mengalami depresi, hal ini tergantung pada kemampuan seseorang dalam menghadapi permasalahan. Usia merupakan salah satu faktor yang mempengaruhi kemampuan seseorang dalam menghadapi permasalahan (Alligood, 2014) Mengetahui hubungan depresi dengan kualitas hidup pasien GGK berdasarkan tingkatan usia dapat membantu perawat dalam memberikan perawatan sesuai tingkatan usia pasien dan meningkatkan kualitas hidup pasien GGK.

\section{METODE PENELITIAN}

Jenis penelitian ini adalah penelitian kuantitatif dengan pendekatan korelasi deskriptif. Tingkat depresi menggambarkan rentang penurunan keadaan jiwa responden yang berkisar antara normal, depresi ringan, depresi sedang, dan depresi berat. Kualitas hidup menggambarkan persepsi seseorang terhadap posisi mereka di dalam kehidupan dalam konteks kesehatan fisik, kondisi psikologis, tingkat ketergantungan, hubungan sosial, dan hal-hal yang menyangkut spiritual. Tingkat kualitas hidup dinyatakan dengan "rata-rata", "diatas rata-rata", dan "dibawah rata-rata". Tingkat usia dikategorikan menjadi dewasa muda (19 - 40 tahun) dan dewasa (41 - 65 tahun).

Pangambilan data dilakukan pada bulan Mei - Juni tahun 2015 di ruang Hemodialisa RSUD dr. Soewondho Kendal. Sampel penelitian berjumlah 42 responden yang diambil dengan teknik purposive sampling sesuai kriteria inklusi dan eksklusi. Data usia dan jenis kelamin diambil dengan kuesioner. Data tingkat depresi diukur dengan kuesioner Zung Self-Rating Depression Scale, sedangkan data kualitas hidup diukur dengan kuesioner The Kidney Disease Quality of Life $\left(\mathrm{KDQOL}^{\mathrm{TM}}-36\right)$. Distribusi frekuensi digunakan untuk mengetahui pengelompokan data responden berdasarkan usia, dan tingkat depresi. Weighted-mean formula dan standar deviasi digunakan untuk mengetahui kualitas hidup responden. Pearson Product-Moment Correlation (Pearson-r) digunakan untuk mengetahui hubungan tingkat depresi dengan kualitas hidup responden. 


\section{HASIL DAN PEMBAHASAN}

\subsection{Tingkat Usia}

Hasil penelitian menunjukkan bahwa sebagian besar responden masuk kedalam kategori usia dewasa $(54,80 \%)$, hal ini mengindikasikan bahwa GGK lebih sering terjadi pada individu usia dewasa daripada individu usia dewasa muda. Kemungkinan penyebab temuan ini adalah banyaknya individu usia 25 tahun keatas menderita hipertensi dan diabetes di Indonesia (suara.com, 2015). Hipertensi dan diabetes sering menyebabkan masalah mikrovaskular yang mengarah pada GGK. Setelah $15-20$ tahun menderita hipertensi dan diabetes, $45 \%$ kasus akan berkembang menjadi GGK. Hal ini menjelaskan mengapa lebih banyak responden masuk dalam kategori usia dewasa.

Tabel 1. Distribusi Frekuensi Responden Berdasarkan Usia

\begin{tabular}{|c|c|c|}
\hline Usia & Frekuensi & $\%$ \\
\hline $\begin{array}{l}\text { Dewasa awal (19-40 } \\
\text { tahun) }\end{array}$ & 19 & 45.20 \\
\hline $\begin{array}{l}\text { Dewasa tengah (41 - } \\
\text { 65tahun) }\end{array}$ & 23 & 54.80 \\
\hline Total & 42 & 100.0 \\
\hline
\end{tabular}

Sumber: Data primer diolah 2015

\subsection{Tingkat Depresi Berdasarkan Tingkatan Usia}

Berdasarkan hasil penelitian diketahui bahwa sebagian besar responden dewasa tidak mengalami depresi $(57,89 \%)$ dan sisanya mengalami depresi ringan $(42,11 \%)$. Sementara itu pada kategori usia dewasa muda 47,83\% responden tidak mengalami depresi, sedangkan sisanya mengalami depresi ringan $(47,83 \%)$ dan berat $(4,34 \%)$. Dari hasil temuan ini dapat disimpulkan bahwa depresi pada pasien GGK dapat terjadi pada siapapun dan kapan pun, namun lebih sering terjadi pada usia dewasa muda.

Depresi merupakan kondisi psikopatologis yang sering terjadi pada pasien GGK. Pasien GGK dewasa muda memiliki risiko lebih tinggi untuk menderita depresi dikarenakan diusia mereka yang masih relatif muda yaitu 19 - 40 tahun, mereka harus menerima kenyataan bahwa mereka menderita penyakit yang tidak mungkin untuk disembuhkan kecuali dengan transplantasi ginjal yang biasanya penyakit ini diderita oleh orang - orang yang usianya lebih tua dari mereka. Perasaan menjadi beban bagi keluarga diusia yang seharusnya masih produktif membuat mereka merasa bersalah dan frustasi. Hal inilah yang menyebabkan penderita GGK usia muda lebih banyak menderita depresi dibandingkan dengan penderita GGk usia dewasa.

Hasil penelitian ini sejalan dengan apa yang disampaikan oleh Terraciano, Milaneschi, Yang An, Ferrucci, dan Zonderman (2013), mereka menyatakan bahwa pola depresi pada orang dewasa mengikuti pola "bentuk U", dimana orang dewasa muda lebih berisiko menderita depresi, menurun selama usia pertengahan, dan meningkat kembali diusia lansia.

Tabel 2. Distribusi Frekwensi Tingkat Depresi Berdasarkan Usia

\begin{tabular}{lcc}
\hline \multicolumn{1}{c}{ Kategori } & Frekuensi & \% \\
\hline Dewasa Muda & & \\
Normal & 9 & 47,83 \\
Ringan & 9 & 47,83 \\
Berat & 1 & 4,34 \\
\hline Total & $\mathbf{1 9}$ & $\mathbf{1 0 0}$ \\
\hline Dewasa & & \\
$\quad$ Normal & 11 & 57,89 \\
Ringan & 9 & 42,11 \\
$\quad$ Berat & 0 & 0 \\
\hline Total & $\mathbf{2 2}$ & $\mathbf{1 0 0}$ \\
\hline
\end{tabular}

Sumber: Data primer diolah 2015

\subsection{Kualitas Hidup Berdasarkan Tingkatan Usia}

Berdasarkan hasil penelitian didapatkan bahwa responden usia dewasa muda memiliki kualitas hidup dibawah rata-rata lebih banyak yaitu $21,05 \%$ dibandingkan responden usia dewasa yang hanya $13,63 \%$. Hasil ini dapat diartikan bahwa orang dewasa muda yang menderita GGK cenderung memiliki kualitas hidup yang lebih rendah bila dibandingkan dengan orang dewasa yang menderita GGK. Kualitas hidup meliputi pemahaman terhadap kondisi fisik dan mental dan hubungan antar keduanya, termasuk kondisi kesehatan, status fungsional, dukungan sosial, dan status sosioekonomi (Oksuz \& Malhan, 2006). 
Tabel 3. Distribusi Frekwensi Kualitas Hidup Berdasarkan Usia

\begin{tabular}{llllllll}
\hline \multirow{2}{*}{ Usia } & \multicolumn{5}{c}{ Kualitas Hidup } \\
\cline { 2 - 8 } & $\begin{array}{c}\text { Dibawah } \\
\text { Rata-rata }\end{array}$ & \multicolumn{2}{c}{$\begin{array}{c}\text { Rata- } \\
\text { rata }\end{array}$} & \multicolumn{2}{c}{$\begin{array}{c}\text { Diatas } \\
\text { Rata-rata }\end{array}$} \\
\cline { 2 - 8 } & $\mathbf{f}$ & $\mathbf{\%}$ & $\mathbf{f}$ & $\mathbf{\%}$ & $\mathbf{f}$ & $\mathbf{\%}$ \\
\hline $\begin{array}{l}\text { Dewasa } \\
\text { Muda }\end{array}$ & 4 & 21,05 & 14 & 73,68 & 1 & 5,26 \\
Dewasa & 3 & 13,63 & 15 & 68,18 & 4 & 18,18 \\
\hline \multicolumn{1}{c}{ Total } & $\mathbf{7}$ & & $\mathbf{2 4}$ & & $\mathbf{1 1}$ & \\
\hline
\end{tabular}

Sumber: Data primer diolah 2015

Dewasa muda dapat dipertimbangkan sebagai masa tersehat dalam hidup dan pada umumnya diusia ini individu dalam keadaan sehat. Erikson (1998), mengatakan bahwa dewasa muda adalah periode dimana orang-orang membuat keputusan penting dalam hidup, seperti menikah, berkeluarga, dan bekerja. Sayangnya, GGK menjadi penghalang bagi mereka untuk dapat melakukan hal-hal tersebut. Ditambah lagi kondisi kesehatan yang tiba - tiba berubah dari kondisi sehat menjadi tidak sehat menyebabkan mereka merasa terjebak dalam penyakit dan dengan semua permasalahan dan komplikasinya, dan mereka memiliki harapan yang tinggi dengan diri mereka mengingat mereka masih muda. Hal inilah yang membuat penderita GGk usia dewasa muda mudah menjadi depresi. Kimmel dan Rosenberg (2014) dalam teorinya menyimpulkan bahwa depresi berkontribusi pada meningkatnya keparahan penyakit GGK yang pada akhirnya akan memperburuk kualitas hidup penderitanya.

Dilain pihak, penderita GGK dewasa memiliki kualitas hidup yang lebih baik. Hal ini dikarenakan mereka telah lebih beradaptasi dengan perubahan kesehatan yang terjadi dan memiliki harapan yang lebih rendah tentang diri mereka dibandingkan penderita GGK dewasa muda. Hal ini sejalan dengan apa yang disampaikan oleh Kader, Myaskovsky, Karpov, dan Dew (2000), penderita GGK dewasa memiliki dikarenakan mereka memiliki dukungan sosial yang lebih baik dibanding penderita GGK dewasa muda.

\subsection{Hubungan Tingkat Depresi Dengan Kualitas Hidup}

Hasil analisis tingkat depresi dengan kualitas hidup diperoleh $r$-value sebesar $-0,450$ dan $p$ - value sebesar 0,000 , artinya ada hubungan yang negatif antara tingkat depresi dengan kualitas hidup pasien GGK di RSUD dr. H. Soewondho kendal. Hubungan yang negatif antara tingkat depresi dengan kualitas hidup berarti semakin tinggi tingkat depresi seseorang, semakin rendah kualitas hidupnya, sebaliknya, semakin rendah tingkat depresi seseorang, semakin baik kualitas hidupmya.

Tabel 4 Hubungan Tingkat Depresi dengan

Kualitas Hidup Pada pasien GGK

di RSUD dr. H. Soewondho Kendal

\begin{tabular}{lcccc}
\hline \multicolumn{1}{c}{ Variables } & $\begin{array}{c}\text { r- } \\
\text { value }\end{array}$ & $\begin{array}{c}\text { p- } \\
\text { value }\end{array}$ & Interpretasi & Decision \\
\hline Tingkat & -0.450 & 0.000 & Significant & Tolak Ho \\
Depresi vs & & & & \\
Kualitas & & & & \\
Hidup & & & & \\
Sumber: Data primer diolah 2015 &
\end{tabular}

Depresi telah dikaitkan dengan memburuknya kualitas hidup dan meningkatkan kesakitan dan kematian diantara pasien GGK. Depresi berpotensi memperburuk kondisi kesehatan pasien GGK melalui beberapa mekanisme. Pertama, stresor psikologis dapat mempengaruhi penerimaan terapi medis. Kedua, depresi juga dihubungkan dengan menurunnya fungsi sistem immun, khususnya penurunan imunitas seluler dan meningkatkan jumlah sitokinin. Ketiga, depresi dikaitkan dengan status nutrisi yang buruk dan menurunnya kadar serum albumin pada pasien GGK. Hasil penelitian ini sejalan dengan temuan Hemati, Alidosti, Sharifirad, dan Kargar (2013) yang mengungkapkan bahwa ada hubungan yang signifikan antara depresi dan kualitas hidup.

\section{SIMPULAN}

Sebagian besar responden masuk dalam kategori usia dewasa $(40$ - 65 tahun) yaitu 23 orang $(54,80 \%)$. Depresi lebih banyak diderita oleh responden usia dewasa muda bila dibandingkan dengan responden usia dewasa, yaitu 47, 83 responden usia dewasa muda menderita depresi ringan dan 4,34\% menderita depresi berat, sedangkan pada responden usia dewasa hanya $42,11 \%$ yang mengalami depresi ringan selebihnya $(57,89 \%)$ tidak mengalami depresi. Kualitas hidup yang rendah lebih banyak ditemukan pada 
reposnden usia dewasa muda bila dibandingkan dengan responden usia dewasa $(21,05 \%$ vs $13,63 \%)$. Ada hubungan yang negatif antara tingkat depresi dengan kualitas hidup dengan $r$ value $-0,450$ dan $p$-value 0,000, yang artinya semakin tinggi tingkat depresi seseorang, semakin buruk kualitas hidupnya.

\section{REFERENSI}

Alligood, M. R. 2014. Nursing theorists and their work $-8^{\text {th }}$ edition. Winsland House, Singapore: Elsevier.

Armaly, Z., Farah, J., Jabbour, A., Bisharat, B., Qader, A., \& Bowirrat. 2012. Major depressive disorders in chronic hemodialysis patients in Nazareth: identification and assessment. Neuropsychiatric Disease and Treatment 2012:8 329-338. Retrieved from: http://dx.doi.org/10.2147/NDT.S31903

Beritasatu.com. 2014. Penderita Gagal Ginjal di Indonesia Meningkat. Retrieved from: http://www.beritasatu.com/riset/102399penderita-gagal-ginjal-di-indonesiameningkat.htm

Charuwanno, R. 2005. The meaning of quality of life among Thai end stage renal disease patients on maintenance hemodialysis. Retrieved from Proquest information and learning company. UMI Number: 3169846

Cukor, D., Cohen, S. D., Peterson, R. A., \& Kimmel P. L.2007. Psychosocial Aspects of Chronic Disease: ESRD as a Paradigmatic Illness. Journal American Society of Nephrology, Vol. 18: 3042-3055. DOI: 10.1681/ASN.2007030345

Erikson, E. H., \& Erikson, J. M. 1998. The life cycle completed (Extended version). New York: W. W. Norton \& Company, Inc

Finkelstein, F.O., Wuerth, D., Troidle, L.K., Finkelstein, S.H. 2008. Depression and end stage renal disease: A therapeutic challenge. Kidney International. Vol. 74, 843-845. DOI: 10.1038/ki.2008.222
Fresenius Medical Care. 2012. ESRD Patients in 2011, A Global Perspective. Retrieved from: http://www.vision-fmc.com/files/ download/ESRD/ESRD_Patients_in_2011.p df.

Hays, R.D., et. al. 1997. Kidney Disease Quality of Life Short Form (KDQOL-SFTM), Version 1.3: A Manual for Use and Scoring. Santa Monica, CA: RAND, P-7994.

Hemati, Z., Alidosti, M., Sharifirad, G., Kargar, M. 2013. The relationship between depression and quality of life among hemodialysis patients in chaharmahal and bakhtiari province in the year 2011. Journal Education Health Promotion, Vol. 2(6). DOI: $10.4103 / 2277-9531.106645$.

Indonesia Ministry of Health. 2014. Profil Kesehatan Republik Indonesia Tahun 2013. Jakarta: Kementerian Kesehatan RI

Kader, K.A., Myaskovsky, L., Karpov, I., Shah, J., Dew, M.A., Unruh, M. 2009. Individual quality of life in chronic kidney disease: Influence of age and dialysis modality. Clinical Journal of the American Society of Nephrology, Vol. 4, 711-718. DOI: 10.2215/CJN.05191008

Kidney Health Australia. 2010. The impact of kidney disease and what Government should be doing about it. Retrieved from: http://www.kidney.org.au/LinkClick.aspx?fil eticket $=\mathrm{oQTbr} / \mathrm{YhZ3c}=$.

Kimmel, P. L., Rosenberg, M. E. 2014. Chronic Renal Disease. Elsevier. Retrieved from: https://books.google.com.ph/books?id=NSK $O A w A A Q B A J \& p g=P A 230 \& d q=$ effect $+o f+d$ epression + to $+E S R D+$ patients $\& h l=e n \& s a=$ $X \& e i=Q f 0 X V f 6 r J o b d m A W o p Y K g A g \& v e d=0$ $C C k Q 6 A E w A A \# v=$ onepage $\& q=$ effect $\% 20$ of \%20depression\%20to\%20ESRD\%20patients $\& f=$ true

Lopez, A.A., Albert, J.M., Young, E.W. Screening for depression in hemodialysis patients: Associations with diagnosis, treatment, and outcomes in the DOPPS. Kidney 
International. 66(6):2486. Retrieved from: http://www.ncbi.nlm.nih.gov/pubmed/15496 178

Oksuz, E., Malhan, S. 2006. Compendium of Health Related Quality of Life. Ankara: Baskent University Publication.

USRDS annual data reports http://www.google. com.ph/url?sa=t\&rct=j\&q=\&esrc=s\&source $=$ web $\& \mathrm{~cd}=4 \& \mathrm{cad}=\mathrm{rja} \&$ uact $=8 \& \mathrm{ved}=0 \mathrm{CDU}$ QFjAD\&url=http $\% 3 \mathrm{~A} \% 2 \mathrm{~F} \% 2 \mathrm{Fwww}$.usrds. org\%2F2012\%2Fpdf\%2Fv2_ch12_12.pdf\& ei=iMkkVamELMPW8gWru4GIBg\&usg=A FQjCNELozzjIHr9GAWmNOmTJ401B3ip7 Q\&sig2=dfN71XaiBLFEfCfnq60cwQ\&bvm $=$ bv. $90237346, \mathrm{~d} . \mathrm{dGc}$
World Health Organization (WHO). 2014. Global health estimates 2014 summary tables: Death by cause, age and sex, by WHO Region, 2000-2012. Retrieved from: http://www.who.int/healthinfo/global_burde n_disease/en/

Zung self-related depression scale. http:// www.google.com.ph/url?sa=t\&rct=j\&q=\&es $\mathrm{rc}=\mathrm{s} \&$ source $=\mathrm{web} \& \mathrm{~cd}=2 \& \mathrm{cad}=\mathrm{rja} \&$ uact $=8$ $\&$ sqi $=2 \&$ ved $=0 \mathrm{CCMQFj} \mathrm{AB} \&$ url $=\mathrm{http} \% 3 \mathrm{~A}$ $\% 2 \mathrm{~F} \% 2$ Flibrary.umassmed.edu $\% 2 \mathrm{Femental}$ health\%2Fclinical\%2Fzung_depression.pdf \&ei=8vkTVf6eJcbv8gXK9YHQCA\&usg=A FQjCNHrGB9c90csXk0hJYDkWeK6OzR8I w\&sig2=3Q7Vee9zhDSVc9bd3HEBPw 